УДК 547.284.5+ 541.61/.614

\title{
A STUDY OF HYPERCONJUGATION EFFECTS IN THE 1,4-DI-p-TOLYLBUTANE-1,4-DIONE STRUCTURE
}

\author{
G. Bagdžiūnas ${ }^{1,2} *$, R. Lytvyn ${ }^{3}$ \\ ${ }^{1}$ Center for Physical Sciences and Technology, \\ Sauletekio av. 3, LT-10257, Vilnius, Lithuania \\ e-mail: gintautas.bagdziunas@gmail.com; \\ ${ }^{2}$ Vilnius University, \\ Naugarduko Str. 24, Vilnius, Lithuania; \\ ${ }^{3}$ Ivan Franko National University of Lviv, \\ Kyryla and Mefodiya Str., 6, 79005 Lviv, Ukraine
}

Planar 1,4-di-p-tolylbutane-1,4-dione was synthesized via one-flask $\mathrm{ZnCl}_{2} \cdot \mathrm{Et}_{3} \mathrm{~N} \cdot \mathrm{t}-\mathrm{BuOH}$ mediated cascade condensation of 4-methylacetophenone and 2-bromo-4'-methylacetophenone. Noncovalent interactions have been analyzed in the solid state from crystal analysis data. Moreover, the hyperconjugation effects in this molecule and n-butane as model have been investigated and compared employing the density functional theory (DFT) and potential energy scans.

Keywords: hyperconjugation, 1,4-di-p-tolylbutane-1,4-dione, density functional theory, potential energy scans, X-ray analysis.

DOI: https://doi.org/10.30970/vch.5902.325

An understanding of the rotation barrier of organic compounds is fundamental for structural theory and the conformational analysis and requires the consistent theoretical models as well as experimental results to differentiate the steric and hyperconjugation effects [1].

It is well known that a hyperconjugation in neutral hydrocarbons is a critical effect for a prediction of possible conformers [2]. For example, the staggered conformer of ethane is most stable. From potential energy (PES) scan of ethane, this had no connection to the amount of electrostatic repulsions within the molecule. These results demonstrate that Coulombic forces do not explain the favored staggered conformations [3]. Moreover, a prediction of molecular structure in the solid and solution state is a key in the material chemistry $[4,5]$ as well as in an investigation of the chiroptical properties of various compounds $[6,7]$.

Single crystals of 1,4-di-p-tolylbutane-1,4-dione were grown from isopropyl alcohol by slow solvent evaporation. The crystal structure from a crystallography analysis is displayed in Fig. 1. The crystal system and space group was determined to be monoclinic and $\mathrm{P} 2 / \mathrm{n}$, respectively. The aromatic p-tolyl moieties are located in a parallel to each other and

(C) Bagdžiūnas G., Lytvyn R., 2018 
partially overlapped. The dihedral angle between them is $0.00^{\circ}$ was estimated from X-ray analysis as well as from optimized structure using DFT. In addition, the energies $\left(\mathrm{E}_{\mathrm{i}}\right)$ of intermolecular interactions in the D1-3 dimers were estimated employing the basis set superposition effect. Due to the parallel structure, the strong face to face $\pi \cdots \pi$ stacking and $\mathrm{C}-\mathrm{H} \cdots \pi$ intermolecular interactions are found (dimer D1 in Fig. 1). For the D1 dimer, the highest interaction energy was estimated to be $-58.4 \mathrm{~kJ} \mathrm{~mol}^{-1}$. Moreover, a close side to side $\mathrm{C}-\mathrm{H} \cdots \mathrm{O}$ hydrogen bond

between the methyl and carbonyl groups is indicated, which connects the $\pi \cdots \pi$ stacked structures (D2 in Fig. 1). For this dimer, $\mathrm{E}_{\mathrm{i}}$ of $-22.9 \mathrm{~kJ} \mathrm{~mol}^{-1}$ was estimated. The D3 dimer with lowest interactions energy of $-8.0 \mathrm{~kJ}^{-1} \mathrm{~mol}^{-1}$ connects only with a weak $\mathrm{C}-\mathrm{H} \cdots \mathrm{H}-\mathrm{C}$ hydrophobic London dispersion force (Fig. 1).
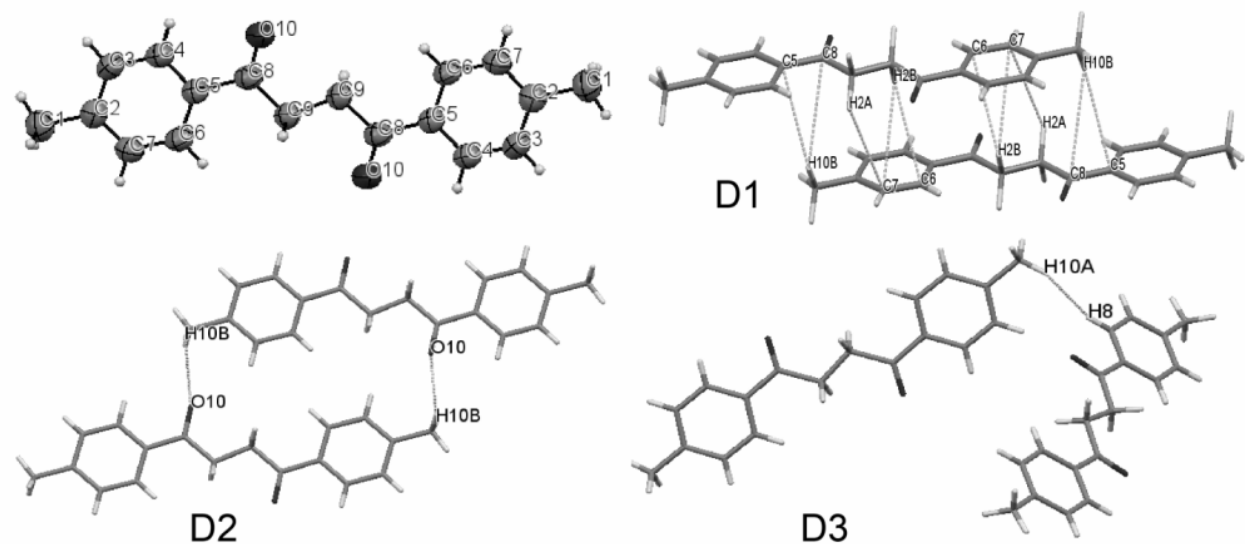

Fig. 1. Crystal structure (probability of ORTEP is $50 \%$ ) and intermolecular interaction between the 1,4-di-p-tolylbutane-1,4-dione molecules

To explain the parallel structure of 1,4-di-p-tolylbutane-1,4-dione, the barriers of rotation between the mid C9-C9' ( $\mathrm{R} 1$ rotation) and conjugated p-tolyl- carbonyl bonds (R2 rotation) in 1,4-di-p-tolylbutane-1,4-dione as well as n-butane $\mathrm{C} 2-\mathrm{C} 3$ bond as model molecule were estimated using PES. For these calculations, high wB97X-D functional with the London dispersion corrections and $6-31 \mathrm{G}(\mathrm{d}, \mathrm{p})$ basis set with the polarization functions on $\mathrm{C}$ and $\mathrm{O}$ atoms and hydrogen was used. First of all, from PES, most stable conformer of this molecule is the same as that obtained from X-ray data. Secondly, the higher full rotation barrier around the mid C9-C9' (R1 rotation) in the molecule than in n-butane was predicted to be 34.5 and $21.6 \mathrm{~kJ} \mathrm{~mol}^{-1}$ in the gas phase, respectively, due to a higher steric repulsion of the p-toluoyl than methyl moieties. However, the rotation barriers from the stable staggered to gauche conformations of 1,4-di-p-tolylbutane-1,4-dione (R1) and nbutane at angle of about $60^{\circ}$ are 4.9 and $13.4 \mathrm{~kJ} \mathrm{~mol}^{-1}$, respectively. Taking into account that the steric repulsion of moieties is not influenced for this rotation, the hyperconjugation effect in the n-butane is 2.7 times higher than in the 1,4-di-p-tolylbutane-1,4-dione case. This effect is called a negative hyperconjugation [8]. For example, Murakami et al. reported that boryl and silyl groups be-have as $\sigma$-acceptors and prefer to rotate inward in the cyclobutene ring-opening reaction despite the steric congestion [9]. For comparison, the rotation between conjugated $\mathrm{p}$-tolyl-carbonyl bonds ( $\mathrm{R} 2$ rotation) was estimated. 
G. Bagdžiūnas, R. Lytvyn

ISSN 2078-5615. Visnyk of the Lviv University. Series Chemistry. 2018. Issue 59. Pt. 1

In this case, the barrier is $28.4 \mathrm{~kJ} \mathrm{~mol}^{-1}$ when p-tolyl and carbonyl moieties are particular to each other. In this case, it is possible to compare the energies in operation of hyperconjugation and conjugation of carbonyl and phenyl moieties. The energy of R2 rotation is 5.8 times higher than rotation energy of negative hyperconjugated mid C9-C9' ( $\mathrm{R} 1$ rotation) was measured. In additional, vibrations between of angles using thermal energy (i.e. $\mathrm{k}_{\mathrm{b}} \mathrm{T}$, where $\mathrm{k}_{\mathrm{b}}$ is Boltzmann constant and $\mathrm{T}=298 \mathrm{~K}$ ) as a threshold of rotation at room temperature were indicated to be $\pm 17^{\circ}$ and $\pm 33^{\circ}$ for the n-butane/ R2 and R1 rotation of the corresponding molecule. Based on the theoretical and experimental data, the intermolecular interactions parallel the 1,4-di-p-tolylbutane-1,4-dione structure in the solid state because the interaction energies are much higher than the hyperconjugation effects.

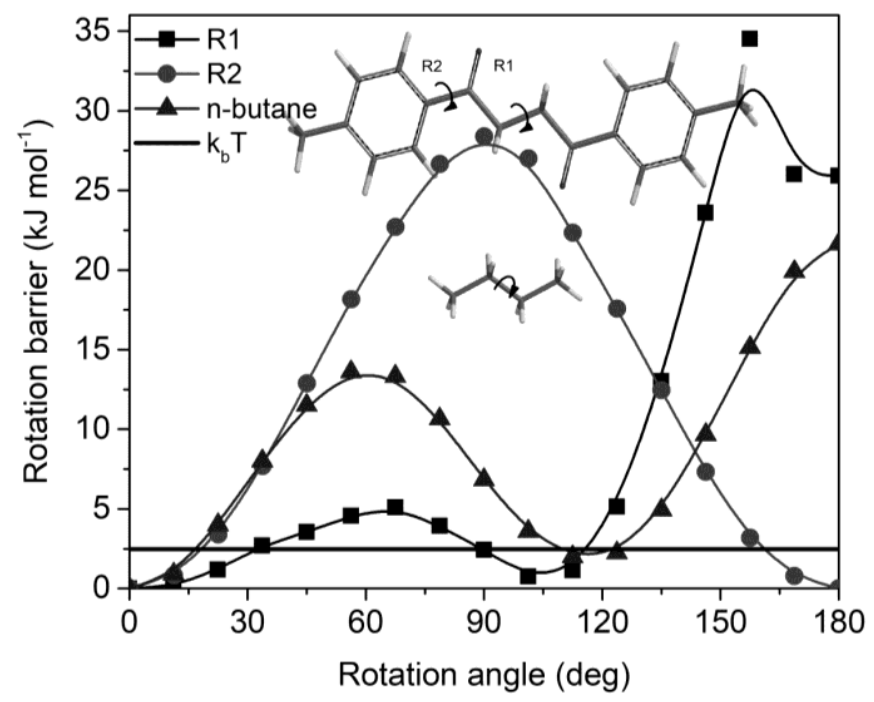

Fig. 2. PES scans of ground sates of 1,4-di-p-tolylbutane-1,4-dione and $\mathrm{n}$-butane (Line of $\mathrm{k}_{\mathrm{b}} \mathrm{T}$ energy is shown in black line)

Because the negative hyperconjugation causes an elongation of the $\sigma$-bond by adding electron density to its antibonding orbital, the bonding highest occupied (HOMO) and antibonding lowest unoccupied (LUMO) molecular frontier orbitals of 1,4-di-ptolylbutane-1,4-dione and n-butane were generated and analyzed (Fig. 3). An electron density on antibonding LUMO is delocalised on the $\pi^{*}$ of conjugated p-toluoyl and small part of $\sigma^{*}$ orbitals of hydrogen of the central ethylene fragment. However, in the n-butane case, the electron density of LUMO exhibits on corresponding central ethylene fragment due to hyperconjugation of the C2-C3 bond. Density of the bonding HOMO orbitals of 1,4di-p-tolylbutane-1,4-dione is delocalized on the $n$ of carbonyl and $\sigma$ orbitals of central ethylene fragment. This is well suited the negative hyperconjugation image.

In additional, a length of the central C9-C9' bond was estimated to be same value of $1.518 \AA$ from X-ray data and DFT calculation, respectively. For comparison, the C2-C3 bond length of n-butane is $1.529 \AA$ at the wB97X-D/6-31G(d,p) theory level. Due to accepting properties of p-toluoyl group, the C9-C9' bond length is lower to be $0.011 \AA$ than corresponding bond in n-butane as model molecule. 


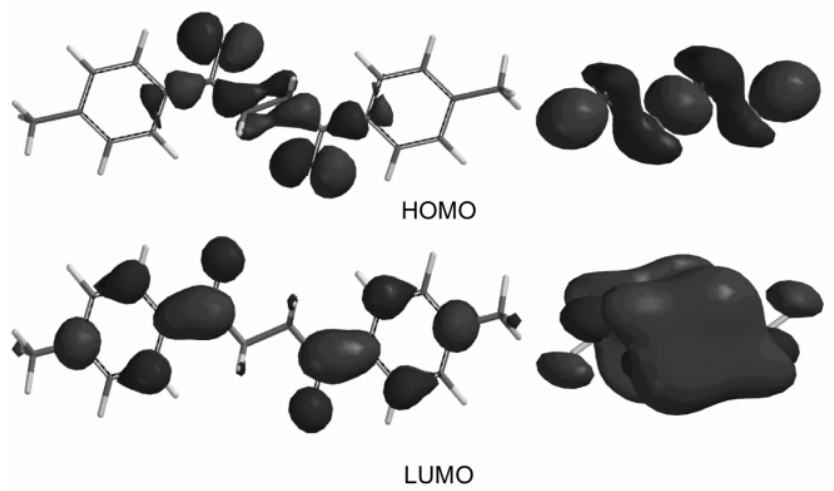

Fig. 3. Frontier HOMO and LUMO orbitals of 1,4-di-p-tolylbutane-1,4-dione and n-butane (isovalue is 0.032 )

1,4-Bis(4-methylphenyl)butane-1,4-dione was obtained by the method close to reported procedure [10].<smiles>CC(=O)c1ccc(C)cc1</smiles>

Commercial anhydrous $\mathrm{ZnCl}_{2}(0.14 \mathrm{~g}, 1.0 \mathrm{mmol})$ was placed into a one-neck, 25 $\mathrm{mL}$ round-bottom flask and dried by melting under vacuum $\left(10-20\right.$ torr) at $250-350{ }^{\circ} \mathrm{C}$ for $15 \mathrm{~min}$. After cooling under vacuum to r.t., toluene $(1.4 \mathrm{~mL})$, triethylamine $(0.104 \mathrm{ml}, 0.75$ $\mathrm{mmol})$, and $t \mathrm{BuOH}(0.07 \mathrm{~mL}, 0.75 \mathrm{mmol})$ were successively added. The mixture was stirred until zinc chloride was fully dissolved (approx. $2 \mathrm{~h}$ ), and 4-methylacetophenone $(0.104 \mathrm{~g}, 0.75 \mathrm{mmol})$ and 4-methylphenacyl bromide $(0.110 \mathrm{~g}, 0.5 \mathrm{mmol})$ were successively added. The mixture was stirred for $1 \mathrm{~h}$, allowed to stand for 4 days at r.t., quenched with $5 \%$ aq $\mathrm{H}_{2} \mathrm{SO}_{4}$ and filtered. Crystalline product were washed successively with benzene, $\mathrm{H}_{2} \mathrm{O}$ and $\mathrm{MeOH}$, and recrystallized from 2-propanol. The 1,4-di-ptolylbutane-1,4-dione was obtained as white crystalline mass $\left(\mathrm{mp}=158-160{ }^{\circ} \mathrm{C}\right)$.

\section{Details of the crystal analysis}

A colourless chip crystal of $\mathrm{C}_{18} \mathrm{H}_{18} \mathrm{O}_{2}$ having approximate dimensions of $0.84 \times 0.11$ x $0.10 \mathrm{~mm}$ was mounted on a glass fibber. All measurements were made on a Rigaku $\mathrm{XtaLAB}$ mini diffractometer using graphite monochromated Mo-K $\alpha$ radiation. The data were collected at a room temperature to a maximum $2 \theta$ value of $55.0^{\circ}$. A total of 540 oscillation images were collected. The structure was solved by the SHELX97 method and expanded using Fourier techniques. The non-hydrogen atoms were refined anisotropically. Hydrogen atoms were refined using the riding model. All calculations were performed using the CrystalStructure crystallographic software package. For the intermolecular interactions visualization, the Mercury 3.7 program was used. CCDC 1587824 contains the supplementary crystallographic data for this paper. These data can be obtained free of charge from the Cambridge Crystallographic Data Centre via www.ccdc.cam.ac.uk/structures. 
Data of crystal analysis of 1,4-di-p-tolylbutane-1,4-dione structure

\begin{tabular}{|c|c|}
\hline Empirical Formula & $\mathrm{C}_{18} \mathrm{H}_{18} \mathrm{O}_{2}$ \\
\hline Crystal Color, Habit & Colorless, chip \\
\hline Crystal Dimensions & $0.84 \times 0.11 \times 0.10 \mathrm{~mm}$ \\
\hline Crystal System/Lattice Type & Monoclinic/Primitive \\
\hline Lattice Parameters & $\begin{array}{l}a=5.6184(10) \AA \\
b=6.482(11) \AA \\
c=20.08(3) \AA \\
\beta=97.25(2)^{\mathrm{o}}\end{array}$ \\
\hline & $V=725(2) \AA^{3}$ \\
\hline Space Group & $P 21^{/ n}(\# 14)$ \\
\hline$Z$ value & 2 \\
\hline $\mathrm{D}_{\text {calc }}$ & $1.219 \mathrm{~g} / \mathrm{cm}^{3}$ \\
\hline $\mathrm{R} 1^{\mathrm{a}}$ & $0.0744^{\circ}$ \\
\hline$w R 2^{b}$ & 0.2459 \\
\hline
\end{tabular}

\section{Details of the theoretical calculations}

The geometry optimizations and single point energy calculations using density functional theory (DFT) in vacuum at $298 \mathrm{~K}$ temperature were performed. The geometry of the compound was optimized by the wB97X-D with the London dispersion corrections functional method and $6-31 \mathrm{G}(\mathrm{d}, \mathrm{p})$ basis set. The intermolecular interaction energies between the molecules in dimers were estimated using the basis set superposition effect (BSSE) concept [11] and at wB97X-D functional and 6-31G(d,p) basis set. The dimers of molecule with intermolecular interactions from the X-ray analysis data were generated. The potential energy (PES) scans of molecule were conducted by rotating the corresponding moieties in steps of $10^{\circ}$ from 0 to $180^{\circ}$ employing the wB97X-D/6-31G(d,p) method. Full optimization of geometries was carried out in PES calculations. All DFT calculations were done with the Spartan'14 program in the gas phase [12].

The synthesized planar 1,4-di-p-tolylbutane-1,4-dione structure has been investigated using crystal analysis and DFT. From the theoretical calculations, a main reason of the structure planarization is intermolecular interactions in the solid state due to a low influence of hyperconjugation.

1. Alabugin I. V., Gilmore K. M., Peterson P. W. Hyperconjugation // WIREs Comput. Mol. Sci. 2011. Vol. 1(1). P. 109-141. DOI: https://doi.org/10.1002/wcms.6

2. Laube T., Ha T. K. Detection of hyperconjugative effects in experimentally determined structures of neutral molecules // J. Am. Chem. Soc. 1988. Vol. 110(16). P. 5511-5517. DOI: https://doi.org/10.1021/ja00224a040 
3. Pophristic $V$., Goodman L. Hyperconjugation not steric repulsion leads to the staggered structure of ethane // Nature 2001. Vol. 411. P. 565-568.

DOI: https://doi.org/10.1038/35079036

4. Reig M., Bagdziunas G., Volyniuk D., Grazulevicius J. V., Velasco D. Tuning the ambipolar charge transport properties of tricyanovinyl-substituted carbazole-based materials // Phys. Chem. Chem. Phys. 2017. Vol. 19 (9). P. 6721-6730. DOI: https://doi.org/10.1039/C6CP08078B

5. Reig M., Gozalvez C., Bujaldon R., Bagdziunas G. et al. Easy accessible blue luminescent carbazole-based materials for organic light-emitting diodes // Dyes and Pigments 2017. Vol. 137. P. 24-35. DOI: https://doi.org/10.1016/j.dyepig.2016.09.062

6. Bagdžiūnas G., Butkus E., Stončius $S$. Synthesis of diastereomeric bicyclo[3.3.1]nonane dibenzoyl esters and study of their chiroptical properties // Chirality 2012. Vol. 24 (10). P. 810-816. DOI: https://doi.org/10.1002/chir.22075

7. Bagdžiūnas G., Butkus E., Stončius S. Homoconjugation vs. exciton coupling in chiral $\alpha, \beta$-unsaturated bicyclo[3.3.1]nonane dinitrile and carboxylic acids // Molecules 2014. Vol. 19 (7). P. 9893-9906. DOI: 10.3390/molecules19079893

8. Exnera $O$., Böhm $S$. Negative hyperconjugation of some fluorine containing groups // New J. Chem. 2008. Vol. 32 (8). P. 1449-1453. DOI: https://doi.org/10.1039/B718430A

9. Murakami, M., Miyamoto, Y., Hasegawa, M., Usui I., Matsuda T. Torque control by metal-orbital interactions // Pure and Applied Chemistry 2009. Vol. 78 (2). P. 415423. DOI: https://doi.org/10.1351/pac200678020415

10. Nevar N. M., Kel'in A.V., Kulinkovich O. G. One step preparation of 1,4-diketones from methyl ketones and $\alpha$-bromomethyl ketones in the presence of $\mathrm{ZnCl}_{2}$. $\mathrm{t}-\mathrm{BuOH} \cdot \mathrm{Et}_{2} \mathrm{NR}$ as a condensation agent // Synthesis 2000. No. 9. P. 1259-1262. DOI: https://doi.org/10.1055/s-2000-6418

11. Boys S. F., Bernardi F. The calculation of small molecular interactions by the differences of separate total energies. Some procedures with reduced errors // Molecular Physics 1970. Vol. 19 (4). P. 553-566.

DOI: https://doi.org/10.1080/00268977000101561

12. Spartan'14 for Windows Version 1.1.2. 1840 Von Karman Avenue, Suite 370, Irvine, CA. 
G. Bagdžiūnas, R. Lytvyn

ISSN 2078-5615. Visnyk of the Lviv University. Series Chemistry. 2018. Issue 59. Pt. 1

\title{
ДОСЛІДЖЕННЯ ЕФЕКТУ ГІПЕРКОН'ЮГАЦІЇ В СТРУКТУРІ 1,4-ДІ-n-ТОЛІЛБУТАН-1,4-ДІОНУ
}

\author{
Г. Багджюнас ${ }^{1,2} *$ Р. Литвин ${ }^{3}$ \\ ${ }^{1}$ Центр фізичних наук та технологій, \\ пр. Саулетекіо, 3, LT-10257 Вільнюс, Литва \\ e-mail:gintautas.bagdziunas@gmail.com; \\ ${ }^{2}$ Вільнюський університет, \\ вул. Наугардуко, 24, Вільнюс, Литва; \\ $3^{3}$ Львівський національний університет імені Івана Франка, \\ вул. Кирила і Мефодія, 6, 79005 Львів, Україна
}

\begin{abstract}
Ротаційні бар'єри в органічних сполуках є одним 3 найголовніших чинників, які впливають на структурні особливості речовини у твердому стані. В свою чергу, просторове розміщення та конформація молекул у твердому стані вирішальним чином впливає на фізичні властивості матеріалів. Очевидно, що конформаційний аналіз органічних сполук є важливим інструментом, не тільки у теоретичному плані, а й має практичне значення для дослідження взаємозалежності структура - властивості. У цій роботі ми досліджували вплив стеричного ефекту та ефекту гіперкон'югації на конформацію модельної сполуки - 1,4-ди- $n$-толілбутан1,4-діону. 3 цією метою отримано 1,4-ди- $n$-толілбутан-1,4-діон за допомогою однореакторної каскадної конденсації 4-метилацетофенону та 2-бромо-4'-метилацетофенону, каталізованої комплексом $\mathrm{ZnCl}_{2} \cdot \mathrm{Et}_{3} \mathrm{~N} \cdot t-\mathrm{BuOH}$. Реакція відбувається протягом 4 днів за кімнатної температури. Вирощено монокристал згаданого діону повільним випаровуванням розчинника 3 розчину ізопропанолу. Проаналізовано нековалентні взаємодії у твердому стані, опираючись на дані рентгеноструктурного аналізу. Побудовано теоретичні моделі димерів 1,4-ди- $n$ толілбутан-1,4-діону. Зроблено порівняльний аналіз ефектів гіперкон'югації для молекул отриманого дикетону та бутану з використанням теорії функціоналу густини (DFT) та зрізів потенціальної енергії (PES). 3'ясовано, що головною причиною планарності 1,4-ди- $n$ толілбутан-1,4-діону у твердому стані $\epsilon$ інтермолекулярні зв'язки у кристалічній решітці, а ефект гіперкон'югації відіграє другорядну роль. Всі теоретичні розрахунки проведено 3 використанням програми Spartan'14 в газовій фазі на рівні теорії густини функціоналу (DFT) методом wB97X-D/6-31G(d,p).
\end{abstract}

Ключові слова: гіперкон'югація, 1,4-ді-пара-толілбутан-1,4-діон, теорія функціоналу густини, зрізи потенціальної енергії, рентгеноструктурний аналіз.

Стаття надійшла до редколегії 1.11.2017 Прийнята до друку 11.04.2018 